Research Article

\title{
Production Economics and Determinants of Carrot (Daucus carota L.) production in Chitwan, Nepal
}

\section{Nabin Pandey*, Swodesh Rijal, Himal Adhikari, Binod Bhantana, Madhusudhan Adhikhari}

\author{
Agriculture and Forestry University, Rampur, Chitwan, Nepal
}

Article Information
Received: 31 August 2020
Revised version received: 17 October 2020
Accepted: 20 October 2020
Published: 29 October 2020
Cite this article as:
N. Pandey et al. (2020) Int. J. Soc. Sc. Manage. 7(4):
234-241. DOI: $10.3126 /$ ijssm.v7i4.32473
*Corresponding author
Nabin Pandey,
Agriculture and Forestry University, Rampur,
Chitwan, Nepal
Email: nabinpandey176@gmail.com
Peer reviewed under authority of IJSSM
() 2020 IJSSM, Permits unrestricted use under the
CC-By-NC license.
OPENOACCESS
This is an open access article \& it is licensed under a
Creative Commons Attribution Non-Commercial 4.0
International
(https://creativecommons.org/licenses/by-nc/4.0/)
Keywords: Gross

\begin{abstract}
Carrot (Daucus carota L.) is an important agricultural commodity in the world. A study was conducted for comparative analysis of demographic, economics assessment, and determinants of carrot production between ward no. 11 and ward no. 15 of the Bharatpur metropolitan of Chitwan district. Altogether 80 carrot growers, 40 from ward no. 11 and 40 from ward no. 15 of Bharatpur metropolitan were randomly selected. Pretested semi-structured questionnaire was used to collect primary information from randomly selected farmers. Carrot growers were interviewed using face to face method in November 2019. Moreover, Two Focus Group Discussion (FGDs) and two Key Informant Interviews (KII) were performed. All the data were entered in Statistical Package for Social Science (SPSS Statistics 20) and Microsoft Excel (Ms-2013) and analysis was done by using Microsoft Excel, SPSS, and Stata. In the majority of respondents, Poultry manure cost $(37.16 \%)$ occupied the major portion of the cost of production followed by seed cost $(30.18 \%)$. The average gross margin per kattha for carrot production found NRs. 4726.62 and the Benefit-cost ratio (BCR) was 1.50 . The probability of cultivation of carrot on large scale was found to be $31.12 \%$ higher for the male gender of household head and $27 \%$ higher for the schooling of the household head. Farmers use the Nepa Drim, F1 variety which incurred higher cost in the seed. Splitting $(26.25 \%)$ was identified as the most critical problem followed by cracking $(21.15 \%)$ in the cultivation of carrot. It is recommended that the farmers involved in carrot farming in the study sites should be provided with Subsidy on seed, proper solution of physiological disorder problems and proper technical knowledge for optimizing the use of resources would help to increase the profit of carrot production in the Chitwan district of Nepal.
\end{abstract}

Keywords: Gross margin; B/C ratio; Probit model; Physiological disorder

\section{Introduction}

Carrot (Daucus carota L.) is one of the most important vegetables belonging to the Apiaceae family (Rubatzky et $a l ., 1999)$. It is a globally grown root vegetable. The color of root flesh may be orange, purple, yellow, white, and red. China, Uzbekistan, Russia, the United States, and Ukraine are the world's top carrot producing countries (Worldatlas, 2017). The estimated global carrot production in 2014 was 38.8 million tons which also forecasted the globally increasing demand for it. The area under carrot in India was 64.33 thousand hectares with the production of 1147.08 thousand metric tons (Sangeetha \& Shanthakumar, 2016). The area, production, and productivity of carrot in Nepal in the year 2015/16 has been reported to be 2933.9 ha, 37724.9 $\mathrm{mt}$, and $12.9 \mathrm{~m} / \mathrm{ha}$ respectively (MoAD, 2015/16, 2017). The average yield of our neighboring countries China and India is 38.54 and 30 tones/ha respectively (Ahmad, 2012). 
In comparison to the global scenario, the reason behind the low productivity in Nepal is inadequate knowledge of the appropriate production method, lack of proper allocation of resources, and topography.

Carrot is a good source of carotenoids, dietary fiber, vitamins, and minerals (Nicolle et al., 2004). It consists of Beta carotene and an appreciable amount of thiamine (Vit $\mathrm{B}_{1}$ ) and Riboflavin (Vit $\mathrm{B}_{2}$ ) (da Silva Dias, 2014). Due to the high availability of carotenoids, carrot can provide us a significant amount of vitamin A (van Het Hof, 2000). As compared to other vegetables, the carrot can contribute more to the human diet. Antioxidant, anti-carcinogen and Immune-enhancer benefits, wound healing, cardiovascular and cholesterol disease lowering, Anti-diabetic, antiinflammatory, antibacterial, and antifungal benefits of carrot have also reported by researchers (Silva Dias, 2014). Besides that, Carrot fleshy roots are used as salads, soups, and used in vegetable dishes (Amjad, 2005).

The production and productivity of carrot in Chitwan was 1437.5 metric ton and 12.5 metric ton/hectare (MoAD, Statistical Information on Nepalese Agriculture 2015/16, 2017). Among different provinces, Bagmati Province is the larger producer of carrot in the country. Chitwan is one of the major carrots producing districts of Nepal. The Released and Registered different varieties of Carrot in Nepal are Nantis ford, New Kuroda, Nepa Drim, F1, Sigma, Kuroda mark, and so on (AITC, 2018). Farmers of Makwanpur district have been growing carrots instead of traditional agricultural products due to high returns in carrot (The Kathmandu Post, 2017). They stopped growing of Maize, millet, beans, and carrot farming can improve living standards through an increase in income. These days, people are more aware of health-conscious and ion healthy diets. An increase in awareness among people about the importance of carrot results in a progressively increase in consumption. The commercialization of carrot can bring unimaginable changes in the living standard of life. Thus, there is great scope for carrot growing farmers to earn a huge amount of income. Moreover, Carrot can be an important vegetable to address food insecurity. So, we need to improve cultivation practices and exploit it to its maximum potentiality. In this context, it is necessary to conduct empirical research to generate knowledge on production economics and determinants of production. Moreover, this study provides information on gross margin and benefits in carrot production, determinants of production, and problems in production.

Table 1: Released and Registered Carrot varieties in Nepal.

\begin{tabular}{|l|l|l|l|l|l|}
\hline $\begin{array}{l}\text { Name of Released } \\
\text { Varieties }\end{array}$ & $\begin{array}{l}\text { Year of } \\
\text { Release }\end{array}$ & Origin & $\begin{array}{l}\text { Yield potential } \\
\text { (Mt/ha) }\end{array}$ & $\begin{array}{l}\text { Maturity } \\
\text { (Days) }\end{array}$ & $\begin{array}{l}\text { Recommendation } \\
\text { Domain }\end{array}$ \\
\hline Nantis Forte & 1990 & India & 12.0 & $90-100$ & High hill \\
\hline New Koruda OP & 2010 & & $50-60$ & 100 & Terai, Mid and high hill \\
\hline Nepa Drim, F1 & 2010 & & 25 & 120 & Terai and hill \\
\hline Sigma, F1 & 2010 & & 25 & 120 & Terai and hill \\
\hline Kuroda Mark & 2010 & & $5-7$ & $50-60$ & Terai and Midhill \\
\hline
\end{tabular}

Source: MoAD, Statistical Information on Nepalese Agriculture 2015/16, 2017.

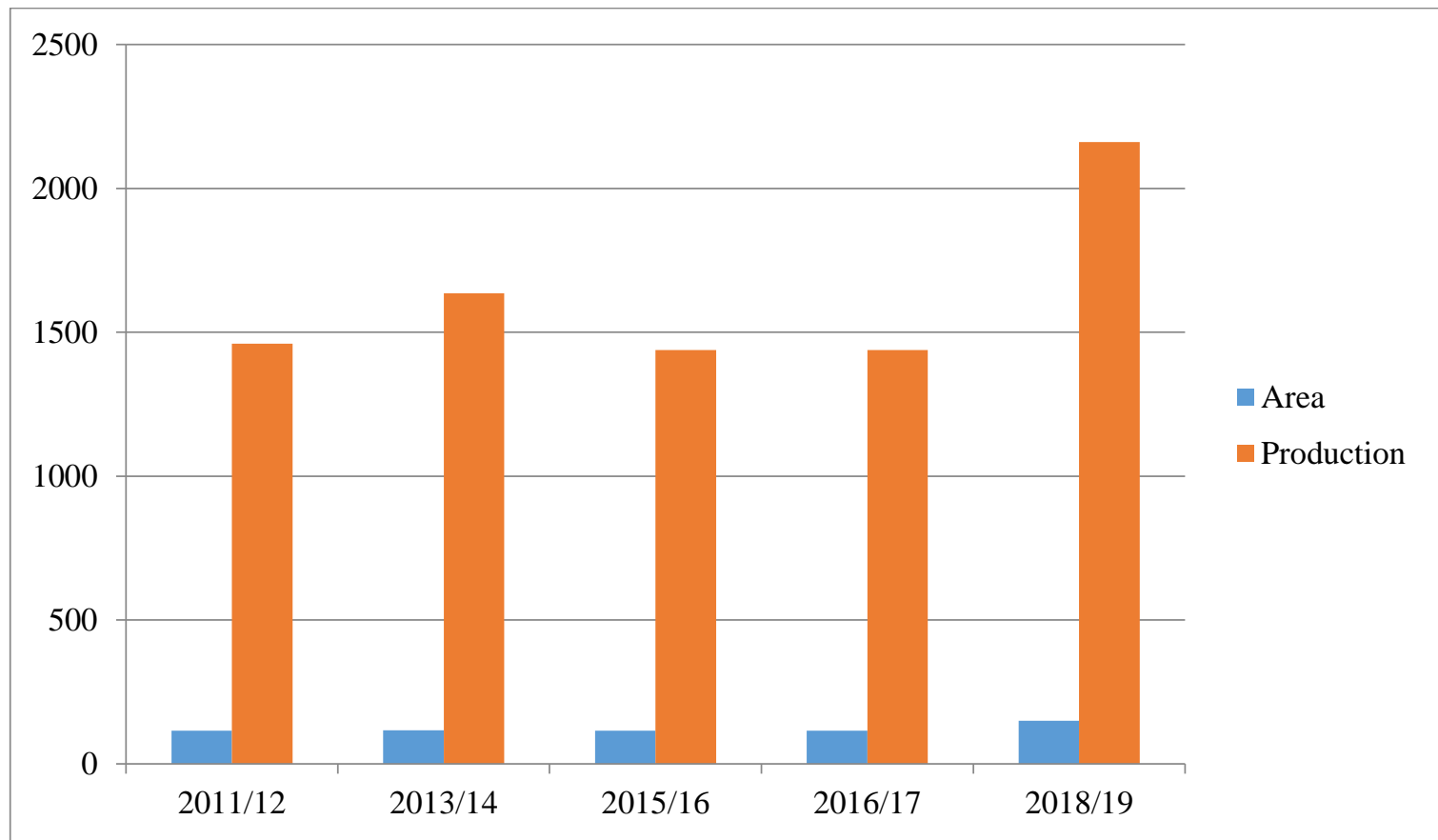

Fig. 1: Production trends of carrot (in metric tons) and area (in hectare) under carrot production in Chitwan district of Nepal. (MoAD, Statistical Information On Nepalese Agriculture, 2011-2020) 


\section{Methodology}

\section{Study Area, Sample Size, and Data Collection Technique}

The research was conducted in ward no.11 and ward no. 15 of Bharatpur Metropolitan of Chitwan district. It is a part of Bagmati province. The district was purposefully selected because it is one of the major carrot producing districts with the identifiable carrot growing farmers. Face to face interview method was used to collect primary data using the pretested semi-structure questionnaire in November 2019. Two Focus group Discussion $\left(\mathrm{FGD}_{\mathrm{s}}\right)$ and two Key Informant Interviews (KII) (Carrot producers, local leaders, Technical assistance, and vegetable zone officer) were performed. The number of relevant literature was reviewed for secondary information. 80 respondents were selected using a Simple random Sampling (SRS) method among farmers cultivating carrot for the last two years. 40 respondents from each ward of Bharatpur Metropolitan were selected (Fig. 1).

\section{Methods and Techniques of Data Analysis}

The data were entered in Statistical Package for Social Science (SPSS Statistics 20) Microsoft Excel (Ms-2013) and analysis was done by using SPSS, Stata, and Microsoft Excel. The following analyses were performed:

\section{Gross Margin}

Gross margin is the difference between gross return and the total variable cost incurred during production. Except for land, Carrot does not require any fixed cost. The gross margin was calculated using the following formula:

Gross margin $=$ Gross return - Total variable cost Where,

Gross return $=$ Price $\times$ Total quantity in the market Total Variable cost $=$ Cost incurred by all variable items.
Adhikari (2009) already used a similar formula to gross margin.

\section{Benefit-Cost Ratio}

The benefit-cost analysis was performed by using the following formula

$\mathrm{B} / \mathrm{C}=\frac{\text { Gross return }}{\text { Total variable cost }}$

This formula was used by (Dahal \& Rijal, 2019) for calculating benefit costs.

\section{Analysis of The Basic of B: C Ratio}

If $\mathrm{B}: \mathrm{C}$ ratio $<1$ then, the enterprise is in Bankrupt condition

If $\mathrm{B}: \mathrm{C}$ ratio $=1$ then, the enterprise is in Just solvent condition

If $\mathrm{B}$ : $\mathrm{C}$ ratio > 1 then, the enterprise is the insolvent condition

\section{Probit Model}

A Probit model was used to determine the factors that influence farmers to cultivate carrot in the large area in Chitwan district. For categorizing the size of the farm, an average farm size of 80 farmers was calculated. Farmers with the landless than the average were considered as smallholder carrot producer and more than that were considered as commercial carrot producers. Farmers of ward no. 15 were commercial carrot producers. The probit model had two categories independent variable and it is the probability model (Liao, 1994). In the binary probit model, Farmers cultivating carrot more than 15 kattha is taken as 1 , while those cultivating less than 15 kattha is taken as zero. It is assumed that the $\mathrm{i}^{\text {th }}$ farmers obtain maximum utility, it has commercial cultivation preference over small farm holders.

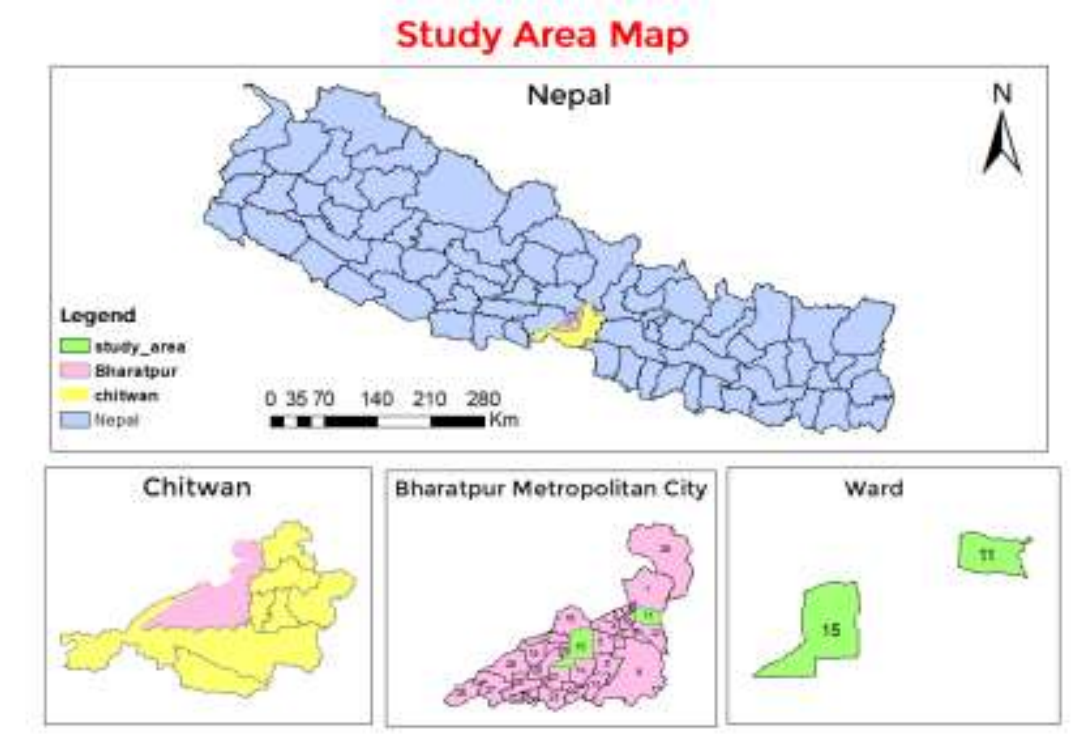

Fig. 2: Map of Research Site. 


\section{Socio-Demographic Characteristics}

The majority of the Household head were male, 32(80.0\%) of the household head of Bharatpur metropolitan ward no. 11 , and $24(60 \%)$ of the household head of Bharatpur metropolitan ward no. 15 were male. The difference was significant at a $10 \%$ level of significance. $97.55 \%$ household head of ward no.11 and $90 \%$ household head of ward no. 15 follow agriculture as the main profession. The majority of the household of both wards was dominated by Brahmin and Chhetri. $80 \%$ household of ward no. 11 and $45 \%$ household of ward no. 15 were Brahmin/Chhetri, $20 \%$ household of ward no. 11 and $25 \%$ household of ward no. 15 were janajati and $30 \%$ household of ward no. 15 belong to Dalit ethnicity. The difference was significant at a $1 \%$ level of significance. $95 \%$ of the household of ward no.11 and $77.5 \%$ household of ward no.15 follow the Hindu religion. Result obtained was significant at a 5\% level of significance. $15 \%$ household of ward no.11 belongs to the joint family whereas $40 \%$ household of ward no. 15 belongs to the joint family. The difference was significant at a 5\% level of significance which was as shown in Table 2.

\section{Cost of Carrot Production}

The total variable cost for carrot production in the study area in one kattha land was calculated NRs. 9290.46. The cost of carrot production in 1 kattha of land was found to be lowest in ward no. 11 of Bharatpur Metropolitan (NRs. 7816) followed by ward no. 15 of Bharatpur Metropolitan (NRs. 10763.26). The profitability of any agricultural production depends on the cost of inputs. The major cost attributing items that were being used are Seed, Land preparation, Farmyard manure, poultry manure, Fertilizers (DAP and Potash), Herbicide cost, Micronutrient (Borax, Zinc), and Labour cost (Planting, weeding, fertilizer application, harvesting, and packing). In the study area, Poultry manure was found to be the first major cost attributing items among all variable items. Seed followed poultry manure in this respect. Herbicide cost was found to be the least cost attributing item. Poultry manure occupied the major portion (37.16\%) of the cost of the production followed by the seed (30.18 \%), Farmyard manure cost (16.51\%), Labour cost
(10.16\%), Micronutrient (Borax and Zinc) cost $(2.60 \%)$, Land preparation cost (1.88\%), Fertilizers cost (1.04\%) and herbicide cost $(0.46 \%)$. Chitwan is the largest producer of poultry products in Nepal. It produces NRs. 1.2 million worth of chickens per week and sales approximately NRs. 213 million worth of poultry manure annually (Thapa, 2016). So, the easy availability of poultry manure in the study area is the major cause of higher use of poultry manure. The cost incurred by seed in the study area was found higher than a similar type of study conducted in the organic and inorganic carrot of Chitwan (Adhikari, 2009) and selected districts of Punjab, Pakistan (Mahmood, 2017) ranges from $10-15 \%$. In the study area, farmers cultivate the Nepa Drim,F1 variety which cost NRs 21500 per kg resulted in higher cost incurred in the seed. The cost incurred in Dap and Potash was lesser than other variables due to lower use of it than the recommended dose. The recommended amount of DAP and Potash are $3.33 \mathrm{~kg} /$ Kattha and $3.33 \mathrm{~kg} /$ Kattha respectively (AITC, 2018). The combination of both organic fertilizer (Farmyard manure and poultry manure) and Inorganic fertilizer (DAP and potash) in the study area are found effective. The influence of poultry manure and NPK (17-17-17) fertilizer on the growth and yield of carrot in Rwanda had found a significant influence on growth and yield of carrot (Habimana, 2014). Similarly, the Application of farmyard manure and inorganic fertilizer in Northern Nigeria are found in increased agronomic parameters of carrot (Ahmed, 2014).

A study conducted on the economics of production of potato in the Saptari district revealed that Seed, plant protection chemicals, DAP, and Potash were underutilized resources in his study (Mahatha, 2012). Also, (Goni, 2013) reported that chemical inputs, seed, and organic manure were underused during dry season vegetable production in Jere Boro state, Nigeria. In contrast to this finding, Chemical fertilizer and labor were overutilized resources in potato production in Guinea (Tolno, 2016). The details of the average cost of production per Kattha are shown in Table 3.

Table 2: Demographic characteristics of carrot growing farmers of the study area

\begin{tabular}{lllll}
\hline & Carrot grown area of Bharatpur & metropolitan & & \\
\hline Variables & Ward no.11 & Ward no.15 & Chi-square & p-value \\
\hline Gender of HHH(Male) & $32(80.0)$ & $24(60.0)$ & $3.81^{*}$ & 0.051 \\
Occupation HHH(Agriculture) & $39(97.5)$ & $36(90.0)$ & $1.92^{\text {ns }}$ & 0.166 \\
Ethnicity & & & \\
Brahamin/chhetri & $32(80.0)$ & $18(45.0)$ & $16.14 * * *$ & 0.000 \\
Janajati & $8(20.0)$ & $10(25.0)$ & & \\
Dalit & 0 & $12(30.0)$ & & \\
Other & 0 & 0 & $5.16^{* *}$ & 0.023 \\
Religion (Hindu) & $38(95.0)$ & $31(77.5)$ & $6.27^{* *}$ & 0.012 \\
Family type(Joint) & $6(15.0)$ & $16(40.0)$ & & \\
\hline
\end{tabular}

Figure in parenthesis indicate percent $* * *$ and $* * *$ indicate $10 \%, 5 \%$ and $1 \%$ level of significance 
Table3: Average cost of carrot production per Kattha*.

\begin{tabular}{|c|c|c|c|}
\hline \multirow[b]{2}{*}{ Cost attributing Items } & \multirow[b]{2}{*}{$\begin{array}{l}\text { The average cost in the Study Area } \\
\text { (**NRs.) }\end{array}$} & \multicolumn{2}{|c|}{$\begin{array}{l}\text { The average cost in Bharatpur } \\
\text { Metropolitan }\end{array}$} \\
\hline & & $\begin{array}{ll}\text { Ward No. } 11 \\
(* * N R s)\end{array}$ & $\begin{array}{lll}\text { Ward } & \text { No. } & 15 \\
(* * \text { NRs }) & & \end{array}$ \\
\hline Seed & 2803.52 & 2363.28 & 3243.76 \\
\hline Land Preparation & 175 & 250 & 100 \\
\hline Farmyard manure & 1534 & 1128.14 & 1939.2 \\
\hline Poultry manure & 3452.15 & 3212.48 & 3691.82 \\
\hline Fertilizers (DAP and Potash) & 97 & 55.97 & 137.25 \\
\hline Herbicide cost & 43 & 53.98 & 31.87 \\
\hline Micronutrient (Borax and Zinc) & 242 & 209.23 & 274.69 \\
\hline \multicolumn{4}{|c|}{$\begin{array}{l}\text { Labour cost (planting, weeding, } \\
\text { fertilizer application, harvesting and }\end{array}$} \\
\hline packing) & 943.79 & 542.91 & 1344.67 \\
\hline Total & 9290.46 & 7816 & 10763.26 \\
\hline
\end{tabular}

* 1 hectare $=30$ Kattha; $* *$ The rate of $1 \$=1$ USD=121.31 NRs. (Nepalese Rupee) as of April 12, 2020.

\section{Gross Return}

The average total returns from carrot production in one Kattha of land in the study area was calculated NRs. 9289.63. The gross return obtained from carrot production in 1 Kattha of land in ward no 15 of Bharatpur metropolitan (NRs. 10763.26) was higher than ward no.11 (NRs. 7816) (Table 3).

\section{Gross Margin}

Gross margin in the study area $=$ Gross return - Total variable cost

= NRs. $(14016.25$ - 9289.63)

= NRs. 4726.62 per Kattha

Gross margin in ward no. 11 of Bharatpur Metropolitan = Gross return - Total variable cost

= NRs. (10912.5 - 7816)

$=$ NRs. 3096.5 per Kattha

Gross margin in ward no. 15 of Bharatpur Metropolitan = Gross return - Total variable cost

= NRs. $(17120-10763.26)$

= NRs. 6356.74 per Kattha

The average gross margin from carrot production in 1 Kattha of land in the study area was calculated NRs. 4726.62. The gross margin in ward no 15 of Bharatpur metropolitan (NRs. 6356.74) was higher than ward no.11 (NRs. 3096.5). The highest gross margin in ward no. 15 was due to having a higher gross return while the lowest gross margin in ward no.11 was due to having the highest cost of production. (Adhikari, 2009) reported that the gross margin for inorganic carrot production per kattha in Chitwan was NRs. 4550.93 (NRs. 136527.84 per hectare). The gross margin is positive which is an indicator of the financial viability of the farm business.

\section{Benefit-Cost Ratio (BCR)}

Benefit-Cost Ratio (BCR) in the study area $=\frac{\text { Gross return }}{\text { Total cost }}$

$=\frac{N R s 14016.25}{N R s .9289 .63}$

$=1.50$

Benefit-Cost Ratio (BCR) in Bharatpur metropolitan ward no. 11

$$
\begin{aligned}
& =\frac{\text { Gross return }}{\text { Total cost }} \\
& =\frac{\text { NRs. } 10912.50}{\text { NRs. } 3096.50} \\
& =1.40
\end{aligned}
$$

Benefit-Cost Ratio (BCR) in Bharatpur metropolitan ward no. $15=\frac{\text { Gross return }}{\text { Total cost }}$

$=\frac{N R s \cdot 17120}{\text { NRs. } 10763.26}$

$=1.59$

The Benefit-Cost Ratio (BCR) of carrot in the study area was calculated 1.50: while the higher BCR was found in Bharatpur metropolitan ward no. 15 (1.59) than ward no.11 (1.40). This indicated that Farmers of ward no. 15 made more profit than farmers of ward no.11. The BCR of our study area was 1.50 which is higher than inorganic carrot $(\mathrm{BCR}=1.44)$ and lower than of organic carrot $(\mathrm{BCR}=1.52)$ (Adhikari, 2009) Moreover, a study carried in selected districts of Pakistan, estimated the benefit-cost ratio of carrot production to be 1.64 (Mahmood, 2017).

The BCR in the study area was found greater than one $(>1)$ shows the feasibility of carrot production in Bharatpur. The BCR of NRs. 1.50 implies that; if we invest one rupee, we can get the returns of Rs 1.50. (Table 4). 
Table4: Economic indicators of the carrot production

\begin{tabular}{llll} 
& Study area & \multicolumn{2}{c}{ Amount in Bharatpur Metropolitan } \\
Items & Amount (NRs.) & Ward No. 11 (NRs.) & Ward No. 15 (NRs.) \\
\hline Total variable cost (NRs./Kattha) & 9289.63 & 7816 & 10763.26 \\
Gross return (NRs./Kattha) & 14016.25 & 10912.50 & 17120 \\
Gross margin (NRs./Kattha) & 4726.62 & 3096.50 & 6356.74 \\
Benefit-cost Ratio (BCR) & 1.50 & 1.40 & 1.59 \\
\hline
\end{tabular}

Source: Field survey, 2019

Table 5: Determinants of commercial carrot production in large scale

\begin{tabular}{lllllll}
\hline Variables & Coefficient & Std. Err. & $\mathbf{t}$ & P>t & \multicolumn{1}{c}{ [95\% Conf. Interval] } \\
\hline Age of HHH (years) & -.0060294 & .0059721 & -1.01 & 0.316 & -.0179375 & .0058786 \\
Gender of HHH (@) & $.3112294^{* * *}$ & .1135559 & 2.74 & 0.008 & .0848054 & .5376534 \\
Schooling of HHH (@) & $.2720669^{* *}$ & .1165513 & 2.33 & 0.022 & .0396702 & .5044636 \\
Occupation of HHH (@) & $.2095892^{*}$ & .1171483 & 1.79 & 0.078 & -.0239978 & .4431763 \\
Access to Extension (@) & $-.1874635^{*}$ & .1001718 & -1.87 & 0.065 & -.3872005 & .0122734 \\
Training received (@) & -.00316 & .0846259 & -0.04 & 0.970 & -.1718993 & .1655792 \\
Member of cooperatives (@) & -.1500775 & .1017141 & -1.48 & 0.145 & -.3528896 & .0527346 \\
Family type (@) & $-.2725401^{* *}$ & .118169 & -2.31 & 0.024 & -.5081625 & -.0369178 \\
Constant & .4661044 & .3046819 & 1.53 & 0.131 & -.141414 & 1.073623 \\
\hline
\end{tabular}

Note: *,** and *** indicate $10 \%, 5 \%$ and $1 \%$ level of significance

Summary Statistics

Number of observation $=80$

$\mathrm{F}=4.76$

Prob $>\mathrm{F}=0.0001$

R-squared $=0.3489$

Adj R-squared $=0.2755$

\section{Probit Model}

A probit model was used to assess the factor influencing the commercial cultivation of carrot on large scale. Among the eight variables studied under the model Gender, Schooling, Occupation, Access to extension worker, and the family type was found to be statistically significant. It has been found that farmers who have access to extension service are more likely to cultivate carrot in a large area compared to those $\mathrm{w}$ without access to extension service (AITC, 2018). Agriculture as the main occupation and access to extension worker was significant at a $10 \%$ level of significance whereas the Schooling of household head and the Family type was significant at a $5 \%$ level of significance. The gender of the Household head was found significant at a $1 \%$ level of significance. The probability of cultivation on large scale was found to be $31.12 \%$ higher for those with male gender of household head and $27 \%$ higher for those with the schooling of the household head. The age of household head, training received and member of cooperative had a negative relation with the commercial cultivation of carrot. The probability of cultivation of carrot on large scale was found to be $21 \%$ higher for the household head with agriculture as the main occupation. Access to extension workers was unlikely to cultivate carrot in a large area by $18.74 \%$. It was found that family type was unlikely to cultivate carrot on large scale by $27.26 \%$.

\section{Problems in Carrot Production}

There are various problems during carrot production. To get a higher yield and maximum profit, we must find appropriate solutions. Chemical use in agriculture in recent years has led to many threats concerning the environment and human health. Trichoderma spp. has been used as a biocontrol agent and is gaining popularity in recent years. Among different disease in study area, fungal disease was havoc. Trichoderma spp. with compatible chemicals is one fungal disease management strategy which would aid in immediate action on plant pathogen and provide control over pathogens in long term as well (Pandey et al., 2019). The farmers have faced problems such as lack of improved varieties and chemical fertilizers, Lack of storage facilities. Splitting and Cracking were major problems found in the study area. It was found that $52.50 \%$ of carrots were in normal condition but $26.25 \%$ and $21.25 \%$ were having cracked and splitting problems respectively. A similar study conducted in the Manahara-Kalimati corridor was found that $10 \%$ and $15 \%$ carrot were found cracked and splitted respectively (Bhattarai, Subedi, Gautam, \& Chauhan, 2017); Table no: 6

Table 6: Problems in carrot production

\begin{tabular}{lll}
\hline Physiological disorder & value & Percentage $(\boldsymbol{\%})$ \\
\hline Splitting & 21 & 26.25 \\
Cracking & 17 & 21.25 \\
Normal & 42 & 52.50 \\
\hline Source: Field survey, 2019 & &
\end{tabular}




\section{Major Physiological disorder}

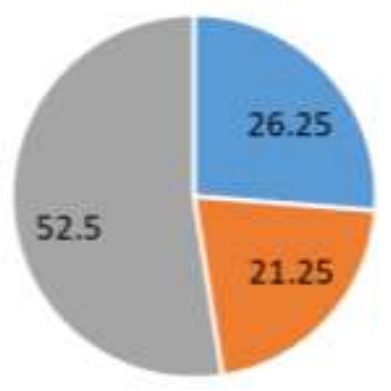

= Splitting $=$ Cracking $=$ Normal

Fig. 3: Diagrammatic representation of major physiological disorder problem in carrot.

\section{Conclusion}

The majority of the household of the research area is male where Brahmin/Chhetri is major ethnicity and agriculture is the main occupation in the research area. The majority of households follow the Hindu religion. The gross margin is a positive and Benefit-cost ratio (BCR) greater than one (1.50), which indicates the financial feasibility of carrot in the Bharatpur metropolitan of Nepal. Poultry manure has occupied a major portion of the cost (37.16\%) among variable cost items. Seed cost has occupied the major portion of the cost of production $(30.18 \%)$; better to follow the recommended seed rate which minimizes the seed cost. Moreover, Subsidy should be provided to the farmers to decrease the cost incurred by seed. The probability of cultivation of carrot on large scale is $31.12 \%$ higher for the male gender of household head and $27 \%$ higher for the schooling of the household head. Splitting (26.25\%) is identified as the most serious problem followed by cracking $(21.25 \%)$ in carrot cultivation. Government, policymakers, and concerned bodies are needed to make proper coordination between them to address these problems. Extension worker must be highly mobilized to provide the knowledge of improved production practices to the farmers. Overall extension approach needs to be improved. Provide loan and subsidy for carrot producer so that they can adopt new innovation.

\section{Authors' Contribution}

N.P, H.A, B.B, M.A; designed the research plan and formulated the household questionnaire. N.P, H. A, B.B and M.A conducted household surveys and tabulated the data. S.R. analyzed the data and performed statistical tests. H.A, N.P, M.A, B.B wrote the manuscript. N.P, M.A, B.B reviewed and finalized the manuscript. All authors have read and approved the final manuscript.

\section{Acknowledgment}

The authors are thankful to all the respondents of ward no.11 and ward no. 15 Bharatpur metropolitan of Chitwan district who provided reliable data to complete this study. We would like to acknowledge Mr. Chandra Prakash Adhikari (Local farmer) for his support and warm cooperation during the study.

\section{References}

Adhikari RK (2009) Economics of organic and inorganic carrot production in Nepal. The Journal of Agriculture and Environment 10: 23-28.

Ahmad TA (2012) Socio-economic study of carrot cultivation at farm level in the Punjab province of Pakistan. African Journal of Agricultural Research, 7(6): 867-875. DOI: https://doi.org/10.5897/AJAR11.1095

Ahmed AS (2014). Response of farmyard manure and inorganic Fertilizers for sustainable growth of carrot (Daucus carota L.) in Northern Nigeria. Journal of Agriculture and Veterinary Science 7(2): 18-25.

AITC. (2018). Krishi Diary. Lalitpur, Nepal: Agriculture Information and Training Centre.

Amjad MN (2005) Growth and seed yield of carrot as influenced by different regimes of nitrogen and potassium. Journal of Research Science 16(2): 73-78.

Bhattarai DR., Subedi GD, Gautam IP \& Chauhan S (2017) Postharvest Supply Chain study of Carrot in Nepal. International Journal of Horticulture 7(26): 239-245.

da Silva Dias JC (2014). Nutritional and health benefits of carrots and their seed extracts. Food and Nutrition Science, 5: 2147-2156.

Dahal BR \& Rijal S (2019). Production Economics and Determinants of Potato production in Nuwakaot, Nepal. Int J Appl Sci Biotechnol 7(1): 62-68.

Goni MU (2013) Analysis of resource use efficiency in dry season vegetable production in Jere Borno State, Nigeria. Journal of Biology, Agriculture and Healthcare 3(19): 18-23.

Habimana SU (2014). Influence of chicken manure and NPK (1717-17) fertilizer on growth and yield of carrot. Net Journal of Agricultural Science 2(4): 117-123.

Liao T (1994). Interpreting probability Models: Logit, Probit and Other Generalized linear Models. California, USA: Saga Publication: Thousand oaks.

Mahatha RK (2012). Economics of production and marketing of potato in Saptari district of Nepal. Doctoral dissertation, Master thesis submitted to Institute of Agriculture and Animal Science, Tribhuvan University, Chitwan, Nepal.

Mahmood IH (2017) Profitability analysis of carrot production in selected districts of Punjab, Pakistan: An empirical investigation. Journal of Applied Environmental and Biological Sciences 7(2): 188-193.

\section{Conflict of Interest}

The authors declare no conflict of interest. 
MoAD (2011-2020) Statistical Information on Nepalese Agriculture. Singha Durbar, Kathmandu Nepal: GON, Ministry of Agricultural Development.

MoAD (2017) Statistical Information on Nepalese Agriculture 2015/16. Singha Durbar, Kathmandu: GON, Ministry of Agricultural Development.

Nicolle C, Simon G, Rock E, Amouroux, P \& Remesy C (2004). Genetic variability influences carotenoid, vitamin, phenolic and mineral content in white, yellow, purple, orange and dark-orange carrot cultivars. Journal of the American Society for Horticultural Science 129:(4): 523529. DOI: https://doi.org/10.21273/JASHS.129.4.0523

Pandey N, Adhikhari M and Bhantana B (2019). Trichoderma and Its Prospects in Agriculture of Nepal: An Overview. International Journal of Applied Sciences and Biotechnology 7(3): 309-316. DOI: https://doi.org/10.3126/ijasbt.v7i3.24337

Rubatzky VE, Quiros CF \& Simon PW (1999) Carrots and related vegetable Umbellifereae. CABI, University of Wisconsin.

Sangeetha S \& Shanthakumar S (2016) Carrot cultivation in India: A critical review. Shanlax International Journal of Arts, Science and Humanities 4(1): 66-71.
Silva Dias JC (2014). Nutritional and Health Benefits of Carrots and their Seed extracts. Food and Nutrition Sciences 5: 2147-2156.

Thapa A (2016) Chitwan; the poultry hub and a center of business activities. EcoNews. Retrieved from http://dynamicthapaspace.blogspot.com/2016/11/chitwan -poultry-hub-and-center-of.html

The Kathmandu Post. (2017, March 07). Jurikhet farmers turn to growing carrots. Retrieved from https://kathmandupost.com/money/2017/03/07/jurikhetfarmers-turn-to-growingcarrots\#: :text=Many\%20farmers\%20in\%20Jurikhet $\% 20$ village, beans $\% 20$ because $\% 20$ of $\% 20$ high $\% 20$ returns.\&te $\mathrm{xt}=$ Carrot $\% 20$ farming $\% 20$ was\%20introduced\%20in,Ran a\%20Magar\%20and\%20Sitaram\%20Thapa.

Tolno EK (2016) Potato production and supply by smallholder farmers in Guinea: an economic analysis. Asian Journal of Agriucultural Extension 8(3): 1-16.

van Het Hof KH (2000) Dietary factors that affect the bioavailabillity of Carotenoids. The Journal of nutrition, 130: 503-506.

Worldatlas (2017). The world's Top carrot producing countries. worldatlas.com. 